Шумаков И. В., д. т. н., доцент,

зав. кафедрой технологии строительного производства,

凶 shumakov.hisi@gmail.com $\%$ +38 (097) 9413328 ,

Юнис Башир, к.Т.н.,

доцент кафедры строительной механики,

凶 docbasheer01@gmail.com ๙ +38 (093) 66104 94,

Ассаад Мустафа, аспирант,

凶 moustapha k88@hotmail.com \% +38 (093) 7947394

Харьковский национальный университет строительства

и архитектуры (ХНУСА), ул. Сумская, 40, г. Харьков, 61002

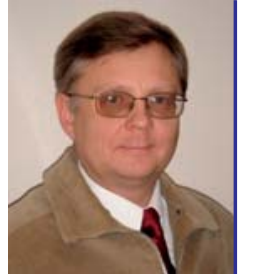

Шумаков И.В.

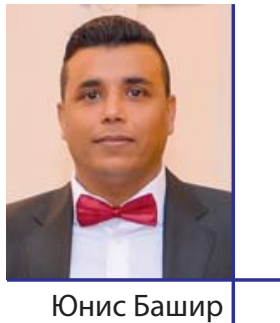

Юнис Башир

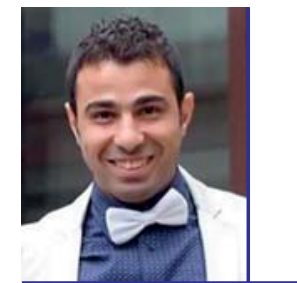

Ассаад Мустафа
Igor Shumakov, D.SC,

Head. the Department of construction technologies,

凶 shumakov.hisi@gmail.com $\approx+38$ (097) 94133 28,

Basheer N. Younis., Ph. D.,

assistant professor of structural mechanics Department,

凶docbasheer01@gmail.com $\%$ +38 (093) 66104 94,

Assaad Moustapha, postgraduate student,

$凶$ moustaphak88@hotmail.com \$ +38 (093) 79473 94,

Kharkov National University of Civil Engineering and Architecture, Str. Sumy, 40, Kharkov, 61002

\title{
СРАВНИТЕЛЬНЫЕ ТЕХНИЧЕСКИЕ СВОЙСТВА ОПАЛУБОЧНЫХ МАТЕРИАЛОВ ДЛЯ ВОЗВЕДЕНИЯ ЗДАНИЙ В УСЛОВИЯХ СЫРЬЕВОЙ БАЗЫ ЛИВАНА
}

\section{ПОРІВНЯЛЬНІ ТЕХНІЧНІ ВЛАСТИВОСТІ ОПАЛУБНИХ МАТЕРІАЛІВ ДЛЯ ЗВЕДЕННЯ БУДІВЕЛЬ В УМОВАХ СИРОВИННОЇ БАЗИ ЛІВАНУ \\ COMPARATIVE TECHNICAL PROPERTIES OF SHAPED MATERIALS FOR BUILDING BUILDINGS UNDER THE CONDITIONS OF RAW MATERIAL BASIS OF LEBANON}

Анотация. В статье рассмотрен анализ существующих опалубочных систем, применяемых в строительстве Ливана, а также сравнение их конструктивно-технологических характеристик. Обзор современных требований к строительству в Ливане и выявление перспектив применения несъёмных систем опалубки в строительной практике.

Ключевые слова: опалубка, лесной ресурс, магнезиальное вяжущее, стеновые конструкции.

Анотація. У статті розглянуто аналіз існуючих опалубних систем, що застосовуються в будівництві Лівану, а також порівняння їх конструктивно-технологічних характеристик. Огляд сучасних вимог до будівництва в Лівані і виявлення перспектив застосування незнімних систем опалубки в будівельній практиці. Ключові слова: опалубка, лісовий ресурс, магнезиальное в'яжучий, стінові конструкції.

Ключевые слова: Ткаустический магнезит, вибровакуумирование, технология, сжатие, изгиб, прочность.

Annotation. The article analyzes the existing shuttering systems used in the construction of Lebanon, as well as a comparison of their structural and technological characteristics, an overview of modern requirements for construction in Lebanon and the identification of the prospects for the use of non-removable formwork systems in construction practice.

Key words: shuttering, forest resource, magnesian binder, wall constructions.

Введение. В Ливане наблюдается сокращение рынка недвижимости из-за нехватки земли под строительство зданий, относительно низкого спроса на местное жилье со стороны инвесторов Персидского залива и высокой стоимости строительных материалов. В городах возводятся отдельные многоэтажные здания преимущественно на основе методов монолитного домостроения, но они не могут решить всей проблемы жилищного строительства [1]. Доля, занимаемая монолитным строительством в отрасли, перспективы ее увеличения в свете современной экономической и жилищной политики, а также мировой опыт показывает, что формирование рациональных конструктивно-технологических систем каркасно-монолитного гражданского строительства является актуальной задачей для ливанской экономики. Выбор рациональной опалубочной системы с учётом строительного опыта и ресурсного потенциала Ливана позволит существенно развить монолитное строительство в стране.

Целью статьи является анализ существующих опалубочных систем, применяемых в строительстве Ливана, сравнение их конструктивно-технологических характеристик, обзор современных требований к строительству в Ливане и выявление перспектив применения несъёмных систем опалубки в строительной практике.

Опалубочные системы используются для придания монолитным конструкциям определенных параметров (форма, геометрические размеры, положение в пространстве, структура поверхности и др.). Для возведения монолитных зданий в Ливане традиционно применяется способ бетонирования в съёмной опалубке, включающий ее установку и монтаж, заполнение полости бетонной смесью и уплотнение, выдерживание до достижения бетоном распалубочной прочности, распалубка.

Традиционным опалубочным материалов для Ливана является ливанский кедр, известный строительный материал с древних времён (рис. 1).
Монтаж опалубки производят в следующей последовательности: по шаблону из досок изготавливают опорные фермы (количество и шаг ферм в блоке опалубки определяют по несущей способности палубы и весу возводимой на ней конструкции) и на монтажном горизонте из двух или более ферм, объединенных палубой, формируют укрупненные блоки (при возведении конструкций с большим пролетом для увеличения жесткости блок опалубки может дополнительно усиливаться связями) [4]. Параллельно с изготовлением блока производят работы по установке опорных конструкций - клиновых лесов или телескопических стоек. Опалубка монтируется на стойки с помощью крана. Нерациональное использование лесного ресурса Ливана привело к угрожающей вырубке лесов и екологической проблеме ближневосточного региона. Эта проблема рассматривается на государственном уровне и в 2017 г. в Ливане создан «Совет по экобезопасному строительству в Ливане», где были приняты мероприятия по стандартизации и регламент требований к современному строительству в Ливане, которые распространяются на индивидуальное и массовое строительство. Основными требованиями стали ресурсозбережение потенциала Ливана, энергоэффективность, экономичность и снижение влияния строительства на окружающую среду [2].

Применяемые в Ливане деревянные конструкции опалубки не отвечают требованиям к современному экологически безопасному строительству, кроме того требуют наличия подъемных механизмов для заполнения опалубки и распалубки и являются материально и финансово затратными. В современной строительной практике арабских стран для возведения монолитных стен малоэтажных зданий представляется наиболее рациональным использование несъёмной опалубки [3]. B частности, актуальным является применение магнезиального вяжущего для таких опалубок. В целом природные запасы 
магнийсодержащих минералов велики и составляют не менее $8 \%$ земной коры. На Ливан приходится большая доля этих запасов. Выбор материала для несъёмной опалубки зависит от требований к зданию, условий эксплуатации и финансовых возможностей. Опалубочная система с применением минерального сырья на основе местных запасов магнезиального вяжущего имеет значительные конкурентные преимущества перед аналогами.

На территории Ливана имеются значительные запасы минеральных материалов, использующихся для строительства. Это известняки, песчаники, мергели, песчано-гравийные смеси, гравий, магнезиальное сырье для вяжущего, известняки-ракушечники, керамзитовые глины [4].

Как правило, месторождения имеют промышленное значение, т.к. благодаря горно-геологическим условиям залегания позволяют вести открытый способ их разработки; они расположены вблизи мест сосредоточенного строительства, транспортных магистралей и источников электроэнергии.

С учетом таких территориальных и экономических преимуществ предложена несъемная опалубка с применением магнезиального вяжущего. Она состоит из модулей с продольными блоками, жестко объединенными прямоугольными рамами и заполнителей (рис. 2).

Прочностные характеристики конструкции, возведённой таким способом, зависит от взаимодействия конструкции опалубки с бетонным сердечником. Влияние состава бетона на прочность сцепления с внутренней поверхностью сердечника зависит от качества и количества цементного теста, применяемых добавок и от фракции заполнителя. Применение несъемной опалубки в строительной практике Ливана наиболее актуально на наш взгляд для малоэтажных зданий, это сокращает продолжительность строительства

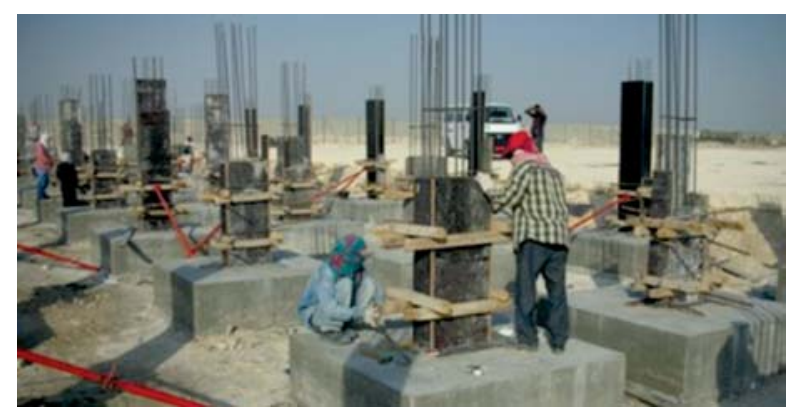

Рис. 1. Применение деревянных конструкций для опалубок

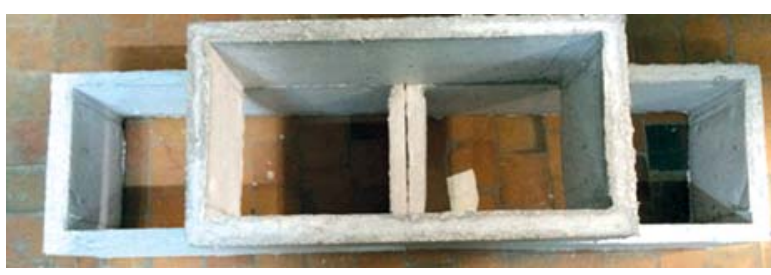

Рис. 2. Общий вид блоков несъемной опалубки
Таблица 1

Сравнение популярных опалубочных материалов Ливана

\begin{tabular}{|c|c|c|}
\hline $\begin{array}{l}\text { Материалы и конструк- } \\
\text { ции для возведения стен }\end{array}$ & $\begin{array}{c}\text { Плотность, } \\
\mathrm{kr} / \mathrm{m}^{3}\end{array}$ & $\begin{array}{l}\text { Толщина изоля- } \\
\text { ционного слоя, см }\end{array}$ \\
\hline Железобетон & 2500 & 170 \\
\hline Кирпич глиняный & 1800 & 56 \\
\hline Ячеистый бетон & 600 & 14 \\
\hline $\begin{array}{l}\text { Деревянные конструкции } \\
\text { опалубки }\end{array}$ & 500 & 13 \\
\hline $\begin{array}{l}\text { Несъемная опалубка } \\
\text { с применением магне- } \\
\text { зиального вяжущего }\end{array}$ & 800 & до 5 \\
\hline
\end{tabular}

и финансовые расходы [5]. Помимо этого, стены с несъемной опалубкой значительно тоньше традиционных кирпичных, что позволяет увеличить эксплуатируемую площадь здания.

Из таблицы видно, что среди основных материалов несъемная опалубка имеет наименьший удельный вес и толщину изоляционного слоя для обеспечения нормативного термического сопротивления. При ее применении возводимая монолитная стена с внутренней и внешней стороны защищена тепло- и звукоизоляционной оболочкой. Благодаря такой конструкции стен дома, построенные с применением несъемной опалубки, являются прочными, легкими и очень теплыми. Кроме того минимизируются размеры складских площадей строительной площадки, что позволяет выполнять работы по строительству и реконструкции даже на плотно застроенной территории.

Установлены преимущества несъемной опалубки по сравнению с другими конструктивно-технологическими решениями:

экологичность и недефицитность сырья;

высокие темпы возведения конструкций;

низкая удельная стоимость стеновой конструкции; простая технология производства работ при возведении стен (принцип Лего);

низкая стоимость перевозки;

возможность крестообразного соединения по сравнению с большинством конкурирующих видов несъемной опалубки;

увеличение прочности монолитного соединения угла и стены за счет угловых элементов.

В соответствии с особенностями возводимых конструкций применяют несъемную опалубку в виде облицовочных панелей, армированных панелей, магнезитовых панелей, пенополистирольных пластин и др. [1-4].

Выводы. На основе выполненного анализа опалубочных систем, применяемых в строительстве Ливана, сравнения их конструктивно-технологических характеристик, обзора современных нормативов, получены результаты, свидетельствующие о перспективах применения несъёмных систем опалубки с использованием магнезиального вяжущего.

Литература:

1. Шумаков И.В. Технологическое обоснование перспектив каркасно-монолитного строительства Ливана / И.В. Шумаков, Юнис Башир Н., Ассаад Мустафа // Науковий вісник будівництва : зб. наук. пр. - Харків : ХНУБА, ХОТВ АБУ.2016. - № 1(83). - C. 52-57. - https://vestnik-construction.com.ua/images/pdf/1_83_2016/stroitel_1_83_2016_52_57.pdf

2. Зеленые здания в Ливане: примирение между городом и средой. - Электронный ресурс : режим доступа http://greenarea.me/ar/227710/ - Назв. с экрана.

3. Хаддадин Ияд. Энерго- ресурсосберегающая технология возведения зданий в несъемной теплоизоляционной опалубке : дисс... канд. техн. наук : спец. 05.23 .08 «Технология и организация строительства» / Хаддадин Ияд. СПБ. : СПБГАСУ, 2007. - 189 с.

4. Ливан : недвижимость, строительство. - Элекронный ресурс : режим доступа http://polpred.com/news/?cnt=88\&sector=17 (15.01.2016). - Назв. с экрана.

5. Системы опалубок. - Электронный ресурс : режим доступа http://www.startimes.com/?t=28218155 (18.01.2018). Назв. с экрана.

6. Гнучих Л.А., Черниговский В.А., Шевченко Л.П. Интерактивная система, предназначенная для решения задач, ориентированных на проблемы стройиндустрии // Радиоэлектроника и информатика. - Харьков. - 2002. - №2. - С. 18-20. 